\title{
Problem Focus Coping Model to Face Working Environment Stressors Prevents Unsafe Action among Workers in a Steel Construction Plant
}

\author{
Noeroel Widajati \\ Lecturer in Department of Occupational Health and Safety, Faculty of Public Health, \\ Universitas Airlangga, Kampus C Mulyorejo 60115, Surabaya-Indonesia
}

\begin{abstract}
Social Security Employment Agency East Java also reported that deaths from occupational accidents were mostly in Gresik where 43 people died out of 310 who died in the entire region of East Java. According to Baker (2011), one of the causes of accidents is job stress. One cause of job stress is heavy work pressure.

This study developed a problem focus coping model mechanism against environmental stressors to prevent unsafe work action in steel construction workers at production line. Design used in this study was cross sectional. Respondents studied were as many as 150 individuals who conducted unsafe action, mostly in moderate category, comprising 64 respondents (42.67\%). Indicators of workplace stressors was in moderate category, in which managerial characteristic comprised 90 persons $(60 \%)$ and interpersonal relationships of 100 persons (66.67\%). Effect of coping mechanisms against unsafe action was highly significant with structural coefficient of -0.236 .

Problem focus coping mechanisms negatively affect unsafe action in respondents at production section of the steel construction, meaning that the higher the coping mechanism, the lower the unsafe action experienced by respondents at production section of the steel construction.
\end{abstract}

Keywords: problem focus coping model, environment stressors, unsafe action, workers construction

\section{INTRODUCTION}

Workplace accidents are mostly caused by unsafe behavior. The percentage of causes of accidents, namely $3 \%$ for reasons which can not be avoided (such as natural disasters), besides $24 \%$ due to environment or equipment that do not qualify, and $73 \%$ due to unsafe behavior or human factors (Suma'mur, 1989).

The human factor has a role where the men as the actors work has many shortcomings, such as lack

\section{Corresponding Author:}

Dr. Noeroel Widajati

S.KM., M.Sc, Lecturer

Department of Occupational Health and Safety, Faculty of Public Health, Universitas Airlangga Kampus C Mulyorejo 60115, Surabaya-Indonesia

Email: noeroel2014@yahoo.co.id, noeroel.widajati@gmail.com of knowledge, lack of skills, motivation is not good, physical and mental stress, cause workplace accidents occur, so that not only the working conditions, but human beings as well as operators who have a lot of weakness. ${ }^{1}$

Social Security Agency (BPJS) Employment of East Java Province reported on in 2013 in East Java reached 310 people died from workplace accidents of 17360 cases of accidents. Workers who suffered permanent disability and disabled people as much as 6476 workers function of the $1,875,951$ workers who are actively working. Employment BPJS East Java also reported that deaths from occupational accidents most was Gresik which 43 people died of the 310 workers who died in the entire region of East Java and accident cases was mostly in the age range between 21 years to 35 years. $^{2}$

According to research Baker ${ }^{3}$ one of the causes of accidents are the source of job stress. One cause of work stress is the pressure of work. Heavy work pressure and pressed for time to finish the job can be stressful work 
so that these events can decrease the body's resistance to disease.

Work stress experienced by each individual differently depending on the individual how to deal with stress is called coping. Folkman ${ }^{4}$ define coping strategies as changes in thought and behavior that is used by a person who in the face of pressures from outside and inside caused by the transaction between a person and the environment are assessed as a stressor. Coping will consist of efforts undertaken to reduce the presence of stressors. Coping has been known as a mediator of the demands of work and workers. Coping done to resolve the problem and balance the emotions of individuals in stressful situations.

\section{METHOD}

This study develops a model problem focus coping mechanisms to stressors working environment, prevent unsafe action on steel construction workers on the production line. Design used in this study was cross sectional. In the same period, some activities that analyze the stressors in the work environment that includes managerial characteristics, design work, interpersonal relationships, roles and responsibilities, career development, and working environment (noise, work climate, and dust). This research was conducted in the steel construction company Gresik on all workers in the Fabrication.

\section{RESULTS}

Respondents' characteristics: The research was conducted on a steel construction worker on the production line. Mild stress levels were experienced by as many as 80 workers, stress was as many as 65 workers, and severe stress as much as 5 workers. The characteristics of the research subjects or respondents are presented in Table 1.

Table 1: Characteristics of Respondents, Workers of Production Section in a Steel Construction

\begin{tabular}{|c|c|c|c|c|c|}
\hline No. & Subjects' characteristics & & Notes & Freq. (f) & Percentage (\%) \\
\hline \multirow{4}{*}{1.} & \multirow{4}{*}{ Education } & a. & Bachelor & 5 & 3.33 \\
\hline & & $\mathrm{b}$. & Diploma & 5 & 3.33 \\
\hline & & c. & Vocational School & 60 & 40 \\
\hline & & $\mathrm{d}$. & High School & 80 & 53.33 \\
\hline \multirow{5}{*}{2.} & \multirow{5}{*}{ Tenure } & a. & $<3$ Years & 80 & 53.33 \\
\hline & & $\mathrm{b}$. & $4-6$ Years & 20 & 13.33 \\
\hline & & $\mathrm{c}$. & $7-9$ Years & 20 & 13.33 \\
\hline & & $\mathrm{d}$. & $10-12$ Year $\mathrm{s}$ & 20 & 13.33 \\
\hline & & e. & $>12$ Years & 10 & 6.67 \\
\hline \multirow{4}{*}{3.} & \multirow{4}{*}{ Age } & $\mathrm{a}$. & 21 years sd 30years & 80 & 53.33 \\
\hline & & $\mathrm{b}$. & 31 years sd 40 years & 40 & 26.67 \\
\hline & & $\mathrm{c}$. & 41 years sd 50 years & 25 & 16.67 \\
\hline & & d. & $>50$ years & 5 & 3.33 \\
\hline \multirow{3}{*}{4.} & \multirow{3}{*}{ Stress level } & a. & High & 14 & 9.33 \\
\hline & & $\mathrm{b}$. & Moderate & 86 & 57.33 \\
\hline & & c. & Low & 50 & 33.33 \\
\hline
\end{tabular}

Table 1 shows that the respondents in this study mostly educated well enough that senior high school, but the number that most are educated high school is $80(53.33 \%)$ of workers, while vocational amounted to $60(40 \%)$ workers. Judging from his past is still relatively low when compared with the longest tenure is 15 years. Jobs in the company of heavy equipment is at risk of an accident steel construction work, so this should be a reliable worker skills. Age-owned steel construction workers in this study pertained mostly young adults are in the age range 21 years to 30 years as many as 80 workers $(53.33 \%)$, thus psychologically emotional still prominent, and the results of the study are mostly located in stress levels were respectively 86 people $(57.33 \%)$. 
Table 2. Frequency Distribution of Unsafe Actions in Steel Construction Workers

\begin{tabular}{|c|c|c|c|c|}
\hline \multirow{2}{*}{ No. } & \multirow{2}{*}{ Score Interval } & \multirow{2}{*}{ Category } & N & Percentage (\%) \\
\cline { 3 - 4 } & & & 6 & 4 \\
\hline 1. & $3.26-4.00$ & High & 64 & 42.67 \\
\hline 2. & $2.51-3.25$ & Moderate & 60 & 40 \\
\hline 3. & $1.76-2.50$ & Less & 20 & 13.33 \\
\hline 4. & $1.00-1.75$ & Low & 150 & 100 \\
\hline & Total & & & \\
\hline
\end{tabular}

Table 2 shows that of the 150 respondents surveyed who perform unsafe acts the most in the category of moderate, namely 64 respondents $(42.67 \%)$.

Environmental Stressors In Steel Construction Workers at Production Section

Table 3: Respondents' Response Distribution On Stressor Indicators

\begin{tabular}{|c|c|c|c|c|c|c|c|c|c|c|}
\hline \multirow{2}{*}{$\begin{array}{c}\text { Working Environment } \\
\text { Stressor Indicators }\end{array}$} & \multicolumn{9}{|c|}{ Respondents' response } & \multicolumn{2}{|c|}{ Total } \\
\cline { 2 - 12 } & \multicolumn{2}{|c|}{ High } & \multicolumn{1}{|c|}{ Moderate } & \multicolumn{2}{|c|}{ Less } & \multicolumn{2}{c|}{ Low } & \multicolumn{2}{|c|}{} \\
\cline { 2 - 13 } & $\mathbf{n}$ & $\mathbf{\%}$ & $\mathbf{N}$ & $\mathbf{\%}$ & $\mathbf{n}$ & $\mathbf{\%}$ & $\mathbf{N}$ & $\mathbf{\%}$ & $\mathbf{n}$ & $\mathbf{\%}$ \\
\hline Managerial characteristics & 21 & 14 & 90 & 60 & 29 & 19.33 & 10 & 6.67 & 150 & 100 \\
\hline Work design & 18 & 12 & 85 & 56.67 & 37 & 24.67 & 10 & 6.67 & 150 & 100 \\
\hline Interpersonal relationship & 20 & 13.33 & 100 & 66.67 & 15 & 10 & 15 & 10 & 150 & 100 \\
\hline Role and responsibility & 5 & 3.33 & 52 & 34.67 & 78 & 52 & 15 & 10 & 150 & 100 \\
\hline Career development & 8 & 5.33 & 20 & 13.33 & 118 & 78.67 & 4 & 2.67 & 150 & 100 \\
\hline
\end{tabular}

Table 3 shows that of the 150 respondents obtained information that the response of employment to environmental stressors of work on indicators of the characteristics of managerial largely being of 90 respondents $(60 \%)$, while the indicator of the design work of most of the respondents have a response with moderate levels of 85 respondents (56, $67 \%$ ). Indicators of interpersonal relationships most respondents had a moderate level of 100 (66.67\%), while the roles and responsibilities of the majority of the respondents have less than 78 responses (52\%). Responder indicator career development largely ie 118 respondents (78.67\%) had a response less.

\section{Job Stress in Steel Construction Workers at Production Section}

Table 4: Distribution Of Respondents Response To Job Stress Indicators

\begin{tabular}{|c|c|c|c|c|c|c|c|c|c|c|}
\hline \multirow{3}{*}{ Job Stress Indicators } & \multicolumn{8}{|c|}{ Respondents' response } & \multirow{2}{*}{\multicolumn{2}{|c|}{ Total }} \\
\hline & \multicolumn{2}{|c|}{ High } & \multicolumn{2}{|c|}{ Moderate } & \multicolumn{2}{|c|}{ Less } & \multicolumn{2}{|c|}{ Low } & & \\
\hline & $\mathbf{N}$ & $\%$ & $\mathbf{n}$ & $\%$ & $\mathbf{N}$ & $\%$ & $\mathbf{n}$ & $\%$ & $\mathbf{N}$ & $\%$ \\
\hline Physical symptoms & 29 & 19,33 & 66 & 44 & 25 & 16,67 & 30 & 20 & 150 & 100 \\
\hline Behavioral symptoms & 28 & 18,67 & 72 & 48 & 35 & 23,33 & 15 & 10 & 150 & 100 \\
\hline Emotional symptoms & 22 & 14,67 & 78 & 52 & 30 & 20 & 20 & 13,33 & 150 & 100 \\
\hline
\end{tabular}

Table 4 shows that respondents to job stress on indicators of physical symptoms mostly have feedback was that 66 respondents (44\%), as well as on indicators of behavioral symptoms showed respondents in the medium category, which is 72 respondents (48\%), as well as on indicators of emotional symptoms most of the respondents had a moderate response, namely 78 respondents $(52 \%)$. 
Coping Mechanisms in Steel Construction Workers at Production Section

Table 5: Frequency Distribution of Coping Mechanisms in Steel Construction Workers

\begin{tabular}{|c|c|c|c|c|}
\hline \multirow{2}{*}{ No. } & \multirow{2}{*}{ Score Intervals } & \multirow{2}{*}{ Categories } & \multicolumn{2}{|c|}{ Frequency } \\
\cline { 3 - 4 } & & & $\mathbf{N}$ & Percentage (\%) \\
\hline 1. & $3.26-4.00$ & High & 38 & 25.33 \\
\hline 2. & $2.51-3.25$ & Moderate & 87 & 58 \\
\hline 3. & $1.76-2.50$ & Less & 15 & 10 \\
\hline 4. & $1.00-1.75$ & Low & 10 & 6.67 \\
\hline & Total & & 150 & 100 \\
\hline
\end{tabular}

Table 5 shows that the respondents to the distrubusi coping mechanisms are mostly located at a moderate level, namely 87 respondents (58\%). The above table explains that most of the respondents have a response to the mechanism of problem focused coping are in the range of scores from 2.51 to 3.25. Problem focused coping done by respondents in the face of environmental stressors tend to work to resolve the problem by seeking information to others, in this case the co-workers, supervisors, and people are more aware of these issues (safety officer).

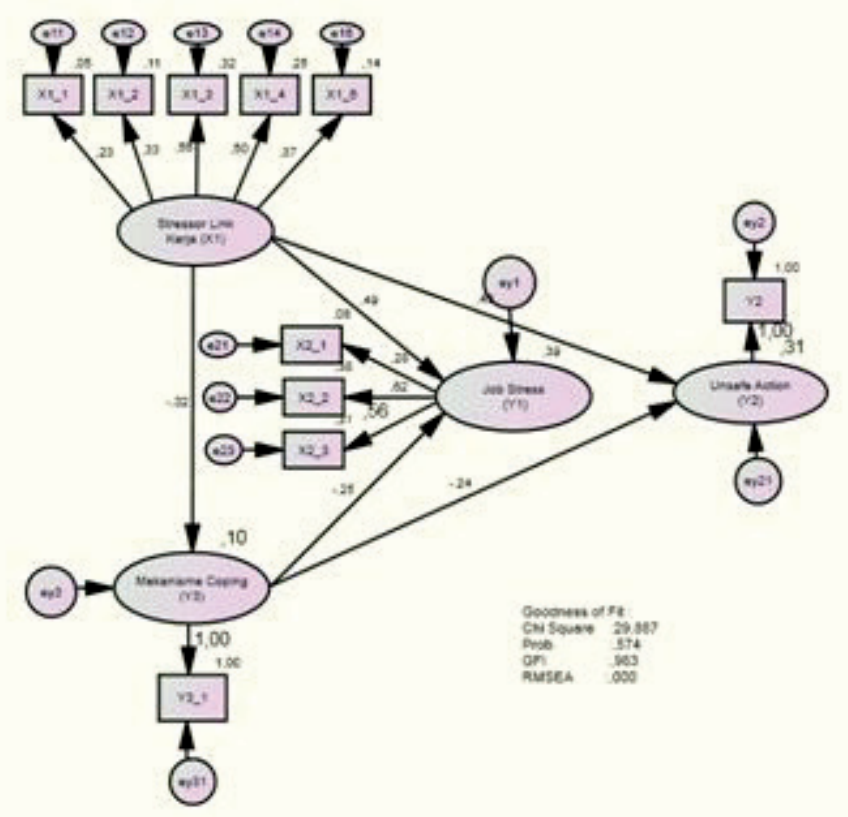

Figure 1: Analysis of standardized solution model test

The image above describes the unsafe action models due to job stress test analysis model of standardized solution. As for the view factor loading of each indicator in the latent variables (constructs) can be explained in Table 6.

Table 6: The Results of Factor Loading of Each Latent Variable Indicators

\begin{tabular}{|c|c|c|c|c|c|c|}
\hline $\begin{array}{c}\text { Latent variables } \\
\text { (Construct) }\end{array}$ & $\begin{array}{c}\text { Variable Indicators } \\
\text { (Observed) }\end{array}$ & $\boldsymbol{\lambda}$ & $\mathbf{p}_{\boldsymbol{\lambda}}$ & $\boldsymbol{\delta}$ & $\mathbf{p}_{\boldsymbol{\delta}}$ & Notes \\
\hline \multirow{4}{*}{$\begin{array}{c}\text { Working } \\
\text { environment stressor }\end{array}$} & Managerial characteristics & 0.228 & 0.000 & 0.150 & 0.000 & Valid and Reliable \\
\cline { 2 - 7 } & Work design & 0.329 & 0.005 & 0.165 & 0.000 & Valid and Reliable \\
\cline { 2 - 7 } & Interpersonal relationship & 0.562 & 0.002 & 0.144 & 0.000 & Valid and Reliable \\
\cline { 2 - 7 } & Role and responsibility & 0.495 & 0.002 & 0.274 & 0.000 & Valid and Reliable \\
\cline { 2 - 7 } & Career development & 0.374 & 0.004 & 0.234 & 0.000 & Valid and Reliable \\
\hline
\end{tabular}


Conted...

\begin{tabular}{|c|c|c|c|c|c|c|}
\hline \multirow{3}{*}{ Job Stress } & Physical symptoms & 0.282 & 0.000 & 0.250 & 0.000 & Valid and Reliable \\
\cline { 2 - 7 } & Behavioral symptoms & 0.619 & 0.000 & 0.215 & 0.000 & Valid and Reliable \\
\cline { 2 - 7 } & Emotional symptoms & 0.555 & 0.000 & 0.372 & 0.000 & Valid and Reliable \\
\hline
\end{tabular}

Table 6 explains that all the indicators that make up the construct stressors working environment consists of indicators of managerial characteristics, design work, interpersonal relationships, the burden and responsibility , and career development is declared valid and reliable. In the construct of job stress all indicators are also declared valid and reliable. The effect of each construct the steel construction workers on the production can be seen in Table 7 .

Table 7: Factors Affecting Unsafe Action

\begin{tabular}{|c|c|c|c|c|}
\hline Independent variables (X) & Dependent variables (Y) & Structural coefficient & $\mathbf{p}$ & Notes \\
\hline \multirow{3}{*}{$\begin{array}{c}\text { Working environment } \\
\text { stressor }\end{array}$} & Coping mechanisms & $-0,323$ & 0,006 & Significant \\
\cline { 2 - 5 } & Job Stress & 0,494 & 0,019 & Significant \\
\cline { 2 - 5 } & Unsafe Action & 0,433 & 0,003 & Significant \\
\hline \multirow{2}{*}{$\begin{array}{c}\text { Problem focus coping } \\
\text { mechanisms }\end{array}$} & Job Stress & $-0,250$ & 0,014 & ignificant \\
\cline { 2 - 5 } & Unsafe Action & $-0,236$ & 0,000 & Significant \\
\hline
\end{tabular}

Table 7 describes the effect of each construct. At construct stressor effect on the working environment problem focus coping mechanisms. It is shown that the $P$ value $p=0.006$, workplace stressor significantly affect job stress and significantly affect the unsafe action with a P value $>\square$. Problem focus coping mechanisms have a very significant influence on job stress and unsafe actions, with a value of $p=0.014$ and $p=0.000$, the overall value of $\mathrm{P}>\square \square$.

The results of the analysis of the data in Table 7 shows the data that the effects of environmental stressors working with unsafe action is very significant with $\mathrm{P}=0.003$ and the value of structural coefficient was 0.433 . The higher the working environmental stressors, the higher the working attitude is not safe or unsafe incident action on workers. Suma'mur ${ }^{1}$ says that the work environment a major effect on worker morale. Factors important state work environment in an industrial accident consists of a household maintenance (housekeeping).

Effect of Working Environmental Stressors on Problem Focused Coping Mechanisms in Workers of Production Section in a Steel Construction: Results loading factor analysis in Table 6 explains that interpersonal relationships contribute most to environmental stressors that work $\lambda=0.562$. Interpersonal relationship in question is the relationship of workers with coworkers, superiors and clients.
Roles and responsibilities in the work environment stressor also donated substantial work with the value $\lambda=0.439$.

Effect of Working Environmental Stressors on Job Stress in Workers of Production Section in a Steel Construction: Distribution of respondents to job stress can be seen by several indicators, namely physical symptoms, symptoms of behavioral and emotional symptoms. Based on the research results can be seen in Table 4 data showed that the indicators of physical symptoms most of the respondents have a poor response of 25 respondents $(16.67 \%)$. This can occur because workers are still lacking or may not even know about the symptoms that occur that can lead to job stress, especially about the physical symptoms of job stress. Workers may also not realize that they had experienced the symptoms that lead to job stress.

Conditions of high workload at the production of steel construction will certainly lead to workers in that section experiencing work stress

The results of the analysis of Table 7 shows that the working environment stressor significant effect on job stress, $\mathrm{P}=0.019$ and 0.494 structural coefficient. Increasingly there are many sources of stress in the workplace, the more the symptoms of stress caused by workers. As well as the beginning of the explanation, the symptoms of stress is very much no physical symptoms, symptoms of behavioral and emotional symptoms. 
According to research conducted by Suharto ${ }^{7}$ says that the stressor physical environment has an indicator which can influence the job stress of a worker, namely the design workspace, design work, lighting systems, air circulation system, the level of visual privacy. While the measuring job stress can be measured through a stomach ache in the works, headache at work, boredom at work, tension in the work, procrastinate, often smoke in the work, often absent from work. This shows that the indicators on the physical environmental stressors variables can give the effect of causing job stress on steel construction workers on the production line.

\section{Effect of Coping Mechanisms on Unsafe Action in} Workers of Production Section in a Steel Construction:

In Table 5, of the 150 respondents who are at coping mechanism categories were as many as 87 respondents $(58 \%)$ are at the level of action being unsafe. Effect of problem focus coping mechanisms against unsafe action is very significant structural coefficient $-0,236$, which its mean when someone is having a problem focus coping rate mechanism of high means the individual can cope with stress in the workplace, the unsafe action taken is lower.

Coping is any individual efforts to set environmental demands and conflicts arising, reducing mismatches/ perception gap between the demands of stressful situations in the individual's ability to meet these demands. Sarafino ${ }^{6}$, problem focused coping (PFC) is a form of coping are more geared to the effort to reduce the demands of stressful situations. artinyacoping that appears focused on individual problems that will cope with stress by studying ways new skills.

\section{CONCLUSIONS}

1. Unsafe action undertaken by respondents at production section in a steel construction tended to violate the SOP, followed by not using PPE (personal protective equipment) or using PPE with improper functions with physical exposure to working environment.

2. Working environment stressors, including managerial characteristics, work design, interpersonal relationships, roles and responsibilities at work and physical factors of work environment, have positive effect on job stress among respondents at production section of the steel construction. The higher the working environmental stressors, the higher the coping mechanisms of the respondents at production section of the steel construction.

3. Working environment stressors, including managerial characteristics, work design, interpersonal relationships, roles and responsibilities in employment and career development, have positive effect on respondents' unsafe action against construction steel in production. The higher the workplace stressors, the higher the unsafe action in respondents at production section of the steel construction.

4. Problem focus coping mechanisms negatively affect unsafe action in respondents at production section of the steel construction, meaning that the higher the coping mechanism, the lower the unsafe action experienced by respondents at production section of the steel construction

Conflict of Interest: This Manuscript has no conflict interest

Source of Funding: This Research was funded by Faculty of Public Health, Universitas Airlangga- Indonesia

Ethical Clearance: This research has passed ethics test based on faculty of Public Health Universitas Airlangga ethical committee KEPK 2016

\section{REFERENCES}

1. Suma'mur. 2009, Higiene Perusahaan dan Kesehatan Kerja (Hiperkes), Sagung Seto: Jakarta.

2. BPJS kesehatan. 2013. Pedoman Administrasi Pelayanan Kesehatan BPJS Kesehatan

3. Baker, Roger. 2011. Understanding Panic Attack and Overcoming Fear. Lion Hudson plc, England.

4. Folkman S, Lazarus RS. An analysis of coping in a middle-aged community sample. Journal of health and social behavior. 1980 Sep 1:219-39.

5. Robbins, Stephen. 1990. Organization Theory: Structure, Design and Applications, Prentice Hall, Inc., Englewood Clifs, New York., 1996, Organizational Behavior: Concepts, Controversies, Applications, 7th ed, Prentice Hall, Inc., Englewood Cliffs, New Jersey 
6. Sarafino, E. P. 1997, Health Psychology: Biopsychology. USA

7. Suharto, Ari. (2014). Pengaruh Stressor Lingkungan Kerja terhadap Kinerja Karyawan melalui Job Stress. Jurnal. Fakultas Ekonomi \& Bisnis Universitas Brawijaya.

8. Suma'mur. 1989. Higene Perusahaan dan Kesehatan Kerja. PT. Toko Gunung Agung. Jakarta.

9. Suma'mur. 2009, Higiene Perusahaan dan Kesehatan Kerja (Hiperkes), Sagung Seto: Jakarta.

10. Bird FE \& Germain GL 1986, Practical Loss Control Leadership, International Loss Control Institute, Loganville, Georgia College, New York.
11. Cooper, C. L, et al 2010, Organizational Stress Management, Palgrave Macmillan, New York

12. Cooper, C. L. \& Williams, S. (1998). "Measuring Occupational Stress: evelopment of the Pessure Management Indicator", Journal of Occupational Health Psychology, vol. 3, no. 4, pp. 306-321

13. Cooper, D. 2001 Improving Safety Culture: A Practical Guide. Hull: Applied Behavioural Science.

14. Cooper, M. D., (2000). Towards a Model of Safety Culture. Safety Science.

15. Keputusan Menteri Tenaga Kerja Nomor 04/ MEN/1987 tentang Panitia Pembina Keselamatan dan Kesehatan Kerja.

16. Widajati, Noeroel. 2015. Model Unsafe Action Akibat Job Stress Pada Pekerja Konstruksi Baja 